\title{
PARTICULATE EMISSION ABATEMENT FOR KRAKOW BOILER HOUSES
}

Quarterly Technical Report

Reporting Period: 10/01/1996 - 12/31/1996

Author: S. Ronald Wysk

Report Issue Date: 01/01/1997

DE-FC22-94PC94111

LSR Technologies, Inc.

898 Main Street

Acton, MA 01720 


\section{Disclaimer}

This report was prepared as an account of work sponsored by an agency of the United States Government. Neither the United States Government nor any agency thereof, nor any of their employees, makes any warranty, express or implied, or assumes any legal liability or responsibility for the accuracy, completeness, or usefulness of any information, apparatus, product, or process disclosed, or represents that its use would not infringe privately owned rights. Reference herein to any specific commercial product, process, or service by trade name, trademark, manufacturer, or otherwise does not necessarily constitute or imply its endorsement, recommendation, or favoring by the United States Government or any agency thereof. The views and opinions of authors expressed herein do not necessarily state or reflect those of the United States Government or any agency thereof. 


\begin{abstract}
$\underline{\text { Abstract }}$
Environmental clean-up and pollution control are considered the foremost national priorities in Poland. The target of this cleanup is the Polish coal industry, which currently comprises over $78 \%$ of primary energy production. This project addresses the problem of airborne dust and uncontrolled particulate emissions from boiler houses, which represents a large fraction of the total in Poland. In Kraków alone, there are more than 2,000 uncontrolled boilers accounting for about half the total fuel use. The large number of low-capacity boilers poses both technical and economic challenges, since the cost of control equipment is a significant factor in the reduction of emissions.
\end{abstract}

A new concept in dust collection, called a Core Separator, is proposed for this important application. The Core Separator is an advanced technology developed through research sponsored by the Department of Energy. It utilizes a highly efficient collector, which functions on the principle of inertial separation. The system is able to control fine particulate matter, as in the $\mathrm{PM}_{10}$ regulations, which limit the emission of dust particles below 10 microns in diameter. Its dust removal performance has been shown to be comparable to a medium-efficiency Electrostatic Precipitator (ESP). Yet, its cost is substantially lower than either an ESP or fabric filter. While the Core Separator achieves high efficiency, its power consumption is just slightly higher than that of a cyclone. It functions dry and without the aid of energy-consuming enhancements. It is simple, reliable, and unlike the ESP and fabric filter, easy to maintain. This combination of features make it ideal for the small boiler market in the City of Kraków.

A highly qualified team has been assembled to execute this project. LSR Technologies, Inc., a technology-based company located in Acton, Massachusetts, is the developer of the Core Separator and holder of its patent rights. LSR has sold several of these units in the U.S. and Europe. EcoInstal, a leading supplier of environmental equipment in Poland, is licensed to sell the Core Separator, and will support LSR as a subcontractor. The Polish Foundation for Energy Efficiency, located in Katowice, is a consulting organization with extensive expertise in the Polish economy and natural environment. FEWE will also be a subcontractor to LSR.

This project will be divided into three major phases. Phase 1 is called "Infrastructure Studies" and will include business planning, and site-selection of a full-scale Core Separator Demonstration Unit. Phase 2, called "Commercial Development", will include the first Demonstration Unit in a local boilerhouse, followed by several Core Separator installations collecting flyash from different Polish coals. Also, a manufacturing facility will be equipped to accommodate the projected sales volume. If the goals of this program are met, and the Core Separator can be successfully marketed, there is a potential to significantly reduce particulate emissions in Kraków. 


\section{$\underline{\text { Table of Contents }}$}

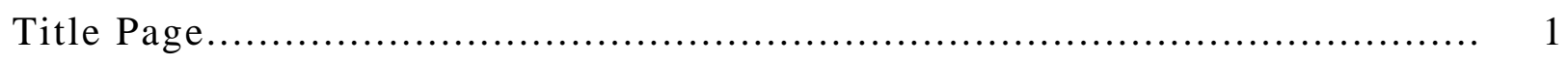

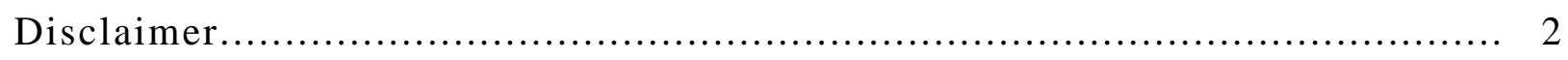

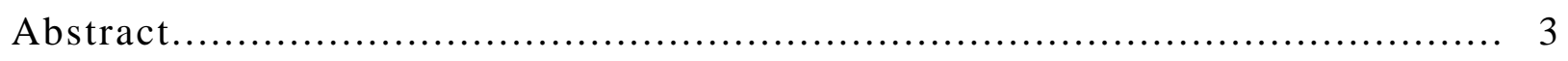

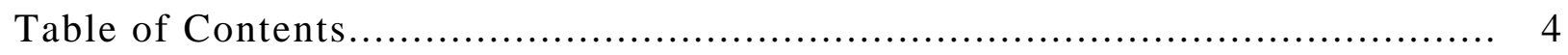

List of Graphical Materials............................................................. 5

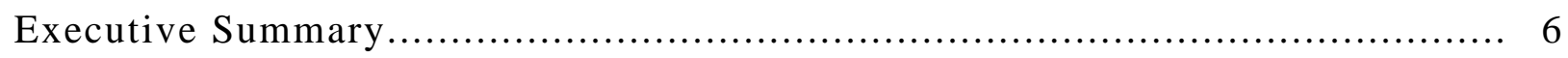

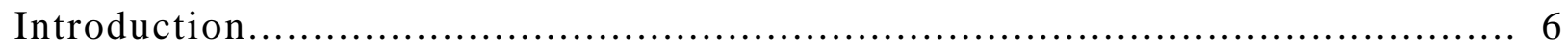

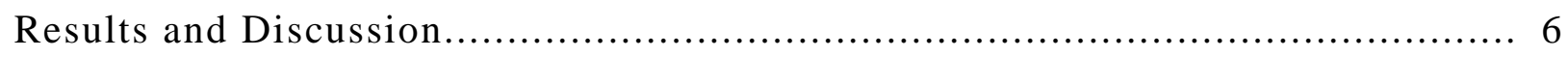

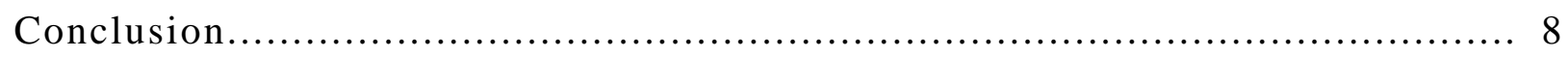

Appendices:

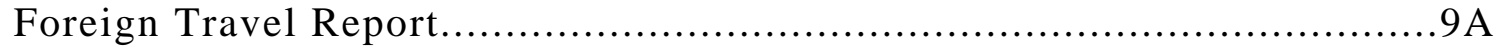

Core Separator Reference List....................................................... 9B

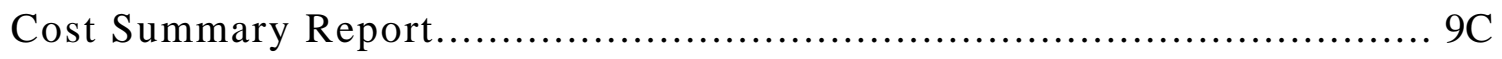

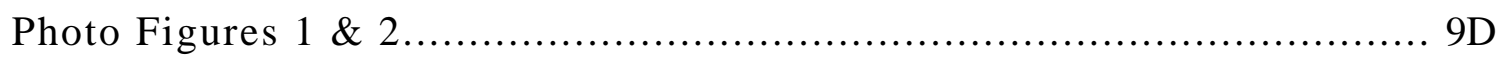

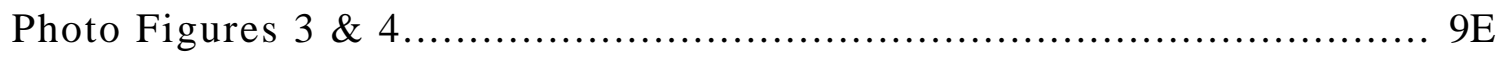

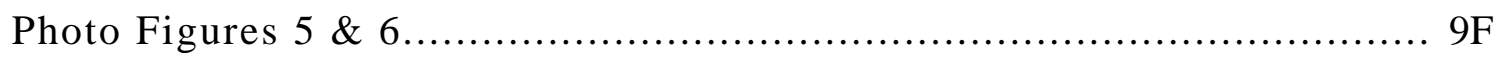




\section{$\underline{\text { List of Graphical Materials }}$}

Core Separator Manufacture by EcoInstal

Core Separator Installation in Kraków

Exhibit of EcoInstal at 1996 Environmental Fair - Poznan
Figures 1 and 2

Figures 3 and 4

Figures 5 and 6 


\section{Executive Summary}

This project involves the implementation of a new particulate control technology called a "Core Separator" for low emission sources (LES) in Kraków. With several hundred boiler sites in the city burning low grade coal, existing pollution control equipment consists primarily of low efficiency cyclones. Such equipment cannot meet the emission standards of most industrial nations. More importantly, these conditions have been the cause of low ambient air quality in Kraków from suspended particles. The Core Separator can be retrofitted onto these boiler houses to substantially reduce particulate emissions, particularly those consisting of the fraction classified as PM10.

\section{Introduction}

In this project, CoreSeparator technology will be demonstrated for boiler house applications in the Kraków region. Phase I entailed business planning and infrastructure studies to determine the market for this equipment. In the second phase, the technology is to be demonstrated in several boilers of different capacity and firing various grades of coal. Later, a joint venture company (JV) was to be established with the capability of manufacturing and supplying this equipment in Kraków and throughout Poland.

The contract between DOE and LSR began April 1, 1994, although DOE permitted some work to commence prior to that time. This report documents work completed during the eleventh quarter, i.e., October 1-December 31, 1996.

\section{Results and Discussion}

Several important accomplishments occurred during the past quarter. A number of significant milestones have been reached that will enable LSR to complete all of its obligations under this project by mid-1997. The following is a summary of those accomplishments:

(1) A License Agreement was signed by LSR and EcoInstal on November 22, 1996. The agreement gives EcoInstal the exclusive right to market and sell Core Separator dust collectors in Poland for an initial period of three years with an option to renew the license through the life of the patent. The license also allows EcoInstal to market our technology in other neighboring countries. A copy of the Patent and Trademark License are attached to 
this report. A copy of the complete agreement between LSR and EcoInstal can also be provided to DOE if requested. This document is considered "proprietary" and we would ask that it not be used outside of DOE.

(2) As of this writing, EcoInstal has commissioned twenty-two (22) Core Separator units in Poland, and two (2) units have been exported to other countries. Eleven (11) other Core Separatordust collectors are under construction as shown in the attached Reference List. Even if no future units were to be sold, the existing Core Separator installations are collectively treating about 350,000 ACFM of dust-laden flue gas, or the equivalent of 300 MWt of boiler output. These units are removing about 5000 tons of dust emissions annually throughout Poland.

(3) One of the units installed this summer is at BUDOSTAL 5 for a rotary drier processing asphalt in Kraków. This unit is not on a coal-fired system and, therefore, was not subsidized by our project.

(4) The largest CoreSeparator to date is being constructed for FIAT AUTO POLAND in Bielsko Biala, about $60 \mathrm{KM}$ from Kraków. This unit will be treating 140,000 M ${ }^{3} / \mathrm{h}$ of flue gas from a WR-25 boiler, and is scheduled for startup in early 1997.

(5) A contract was also received for four (4) new Core Separator units at the Zorza Cooperative Heating Plant in Myslenice (a suburb of Kraków). When complete, there will be nine (9) CoreSeparator installations in Kraków. Of course, there are many other nearby operating units which are in close proximity to the voivoidship of Kraków.

(6) The large environmental fair and trade show, called POLEKO, took place November 19-22 in Poznan. More than 1000 companies from 90 countries participated. EcoInstal displayed an excellent exhibit at this fair and was one of seven companies selected for a special show award. Both EcoInstal and LSR appeared on a local television broadcast in which the companies and Core Separator technology were highlighted.

(7) During the environmental fair, both LSR and EcoInstal met with Mr. Charles Bliss of the U.S. AID to review the progress of our project. Mr. Bliss seemed to be very pleased with the number of CoreSeparator unit sales in our project, and was quite impressed with 
EcoInstal's exhibit. During the trade show, one new Core Separator sale was completed.

(8) Following the signing of our License Agreement, EcoInstal presented a summary of technology transfer costs associated with the Core Separator through May 1996. Based on the combined cost sharing of LSR, EcoInstal, and early users of the technology in Kraków, we should be able to exceed the total contract value of our Cooperative Agreement with DOE.

\section{Conclusion}

The major milestone for this quarter will be the contract with Zorza for the installation of four (4) new dust collectors. The engineering for these units has already been completed. The final installation should be finished during the first quarter of 1997.

The Zorza units when operational will fulfill LSR's obligations under our Cooperative Agreement for number of installations. Following this milestone, we intend to make preparations to close out our contract. Full documentation of all costs and cost sharing will be prepared. Depending on the auditing process, it should be possible to close out this project by July 1, 1997.

Of course, LSR fully intends to continue doing business in all regions of Poland in the near and distant future. 


\section{LSR Technologies, Inc.}

Environmental and Energy-Related Systems

January 2, 1997

Ms. Linda Weightman

Reports Receipt Coordinator

Pittsburgh Energy Technology Center

U.S. Department of Energy

P.O. Box 10940

Pittsburgh, PA 15236-0940

Ref: Foreign Travel Report, "Particulate Emission Abatement in Krakow Boiler Houses," DE-FC22-94PC 94111

Dear Ms. Weightman:

There was one foreign trip made during the 4th quarter 1996 in conjunction with this Cooperative Agreement. This travel took place on November 17-24 and was made by the undersigned in the Republic of Poland. If you require additional information, please let me know.

Sincerely,

S. Ronald Wysk

Managing Director

898 Main Street • Acton Massachusetts 01720-5808 • (508) 635-0123 FAX (508) 635-0058 


\section{Core Separator Reference List}

\begin{tabular}{|c|c|c|c|c|}
\hline Installation & $\begin{array}{l}\text { No. of } \\
\text { Units } \\
\end{array}$ & $\begin{array}{c}\text { Initial } \\
\text { Operation }\end{array}$ & $\underline{\text { Capacity }(\mathrm{M}} \underline{3} / \underline{\mathrm{h}})$ & Application \\
\hline 1. PEC Oborniki & 1 & $4 / 95$ & 10,000 & WR-2.5 Stoker Boiler \\
\hline 2. EXBUD Tarnow & 2 & $5 / 95,6 / 96$ & 5,300 & Fluidized Bed Boilers \\
\hline 3. Kombinat RSP Czempin & 3 & $8 / 95$ & 5,600 & WCO-80 Stoker Boilers \\
\hline 4. PEC Knurow & 1 & $10 / 95$ & 50,000 & WR-10 Stoker Boiler \\
\hline 5. Czech Technical University & 1 & $10 / 95$ & 2,500 & Fluidized Bed Boiler \\
\hline 6. MPK Krakow & 3 & $1 / 96$ & 5,600 & WCO-80 Stoker Boiler \\
\hline 7. Armatura Krakow & 1 & $1 / 96$ & 24,500 & WR-5 Stoker Boiler \\
\hline 8. Institute Non Ferrous Metals & 1 & $6 / 96$ & 12,000 & Copper Smelter \\
\hline 9. Matizol Gorlice & 2 & 3/96 & 10,000 & Asphalt Plant Drier \\
\hline 10. Odlewnia Zeliwa & 1 & $3 / 96$ & 25,000 & OKR-5 Stoker Boiler \\
\hline 11. Argentchem Opalenica & 1 & $6 / 96$ & 800 & Smelting Furnace \\
\hline 12. Klimawentex Rzeszow & 3 & 6/96 & 3,000 & Glassmelting/Sanderdust \\
\hline 13. Budostal Krakow & 1 & $6 / 96$ & 21,600 & Rotary Drier/Asphalt \\
\hline 14. Farbiarski Warsaw & 1 & $6 / 96$ & 9,000 & PCO-60 Heating Boilers \\
\hline Total in Operation & 22 & & 184,900 & \\
\hline \multicolumn{5}{|l|}{ Under Construction } \\
\hline 15. FIAT Auto Poland & 1 & $1 / 97$ & 140,000 & WR-25 Stoker Boiler \\
\hline 16. Krakodlew-Krakow & 1 & 2/97 & 8,000 & Rotary Drier/Sand \\
\hline 17. Cementownia Strzelce & 1 & 2/97 & 10,000 & Cement Kiln Drier \\
\hline 18. Zorza Myslenice & 4 & 3/97 & 8,000 & KRN-1.7 Stoker Boilers \\
\hline 19. Zembiec Zembcu & 1 & 3/97 & 35,000 & Rotary Drier/Bentonite \\
\hline 20. PRD Kutnie & 1 & $3 / 97$ & 45,000 & Rotary Drier/Asphalt \\
\hline 21. PZW Warsaw & 2 & 3/97 & 100,400 & Two Stoker Boilers \\
\hline Total Under Construction & 13 & & 346,400 & \\
\hline Total to Date & 35 & & 531,300 & \\
\hline
\end{tabular}


DOE F 4600.5

$(01-93$

Replaces EIA-459E

All Other Editions Are Obsolete

U.S. DEPARTMENT OF ENERGY

FEDERAL ASSISTANCE MANAGEMENT SUMMARY REPORT

OMB BURDEN DISCLOSURE STATEMENT
OMB Control No.

$1910-0400$

Page 1 of 1

Public reporting burden for this collection of information is estimated to average 3.38 hours per response, including the time for reviewing instructions, searching existing data sources, gathering and maintaining the data needed, and completing and reviewing the collection of information. Send comments regarding this burden estimate or any other aspect of this collection of information, including suggestions for reducing this burden, to Office of Information Resources Management, AD-244-GTN, Paperwork Reduction Project (1910-0400), U.S. Department of Energy, 1000 Independence Avenue, S.W., Washington, DC 20585; and to the Office of Management and Budget (OMB), Paperwork Reduction Project (1910-0400), Washington, DC 20503.

\begin{tabular}{|c|c|}
\hline $\begin{array}{c}\text { 1. Program/Project Identification No. } \\
\text { DE-FC22-94PC94111 }\end{array}$ & $\begin{array}{r}\text { 2. Program/Project Title } \\
\text { Particulate Emission Abatement for Krakow Boiler Houses }\end{array}$ \\
\hline
\end{tabular}

4. Name and Address

LSR Technologies, Inc.

898 Main Street

Action, MA 01720-5808

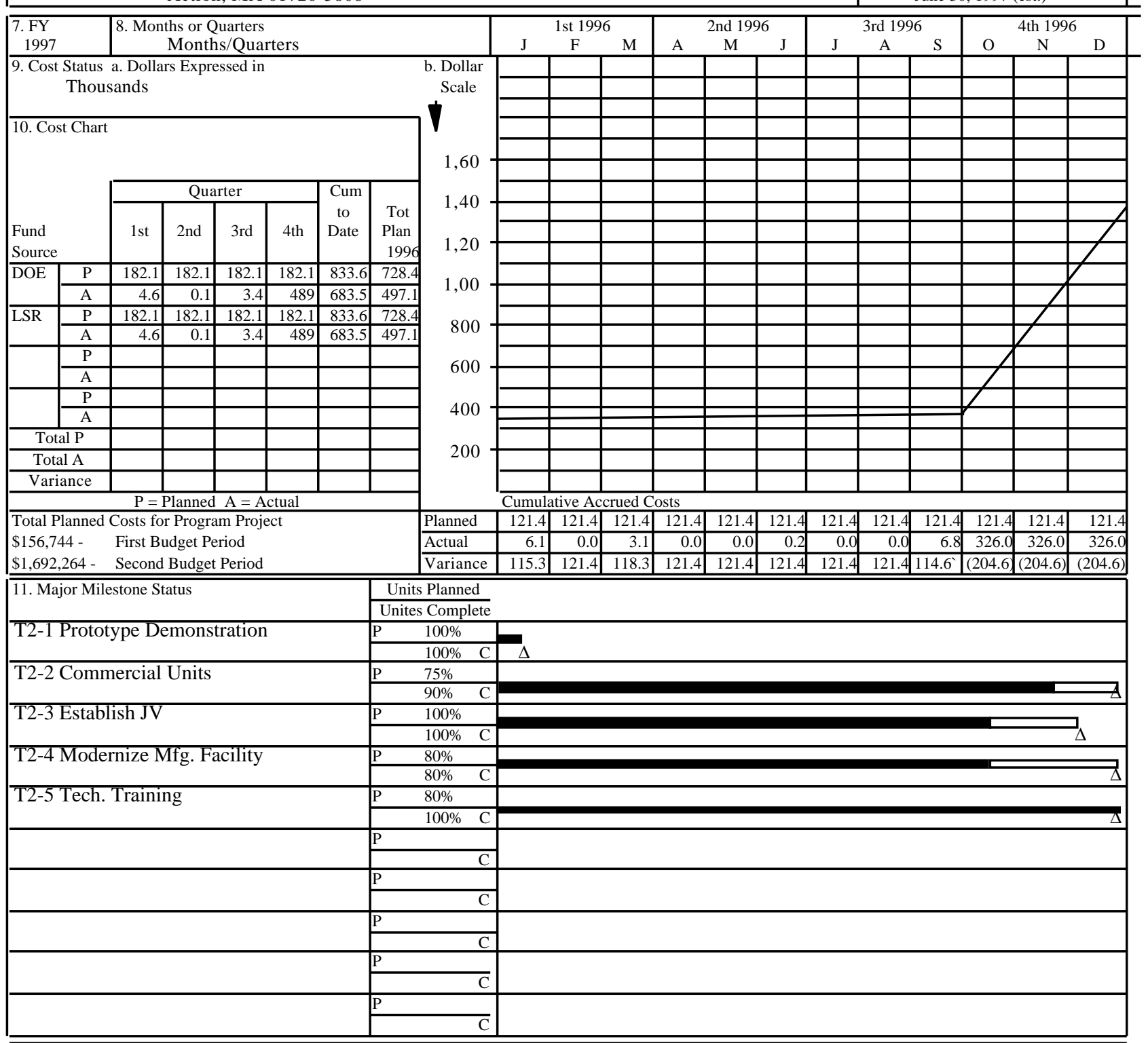

12. Remarks

13. Signature of Recipient and Date

\&.Rellype

14. Signature of U.S. Department of Energy (DOE) Reviewing Representative and Date 
Figure 1

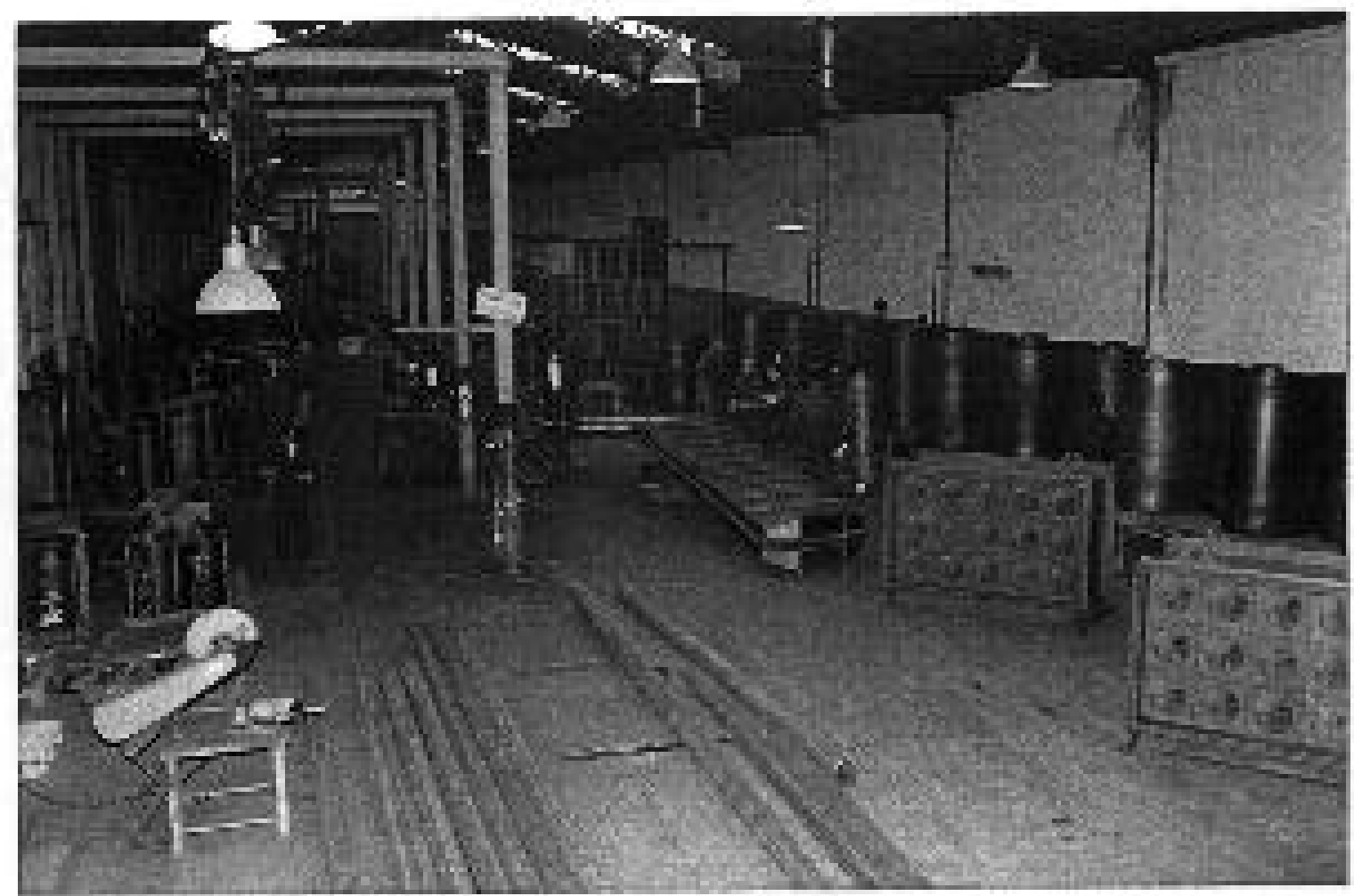

Figut?

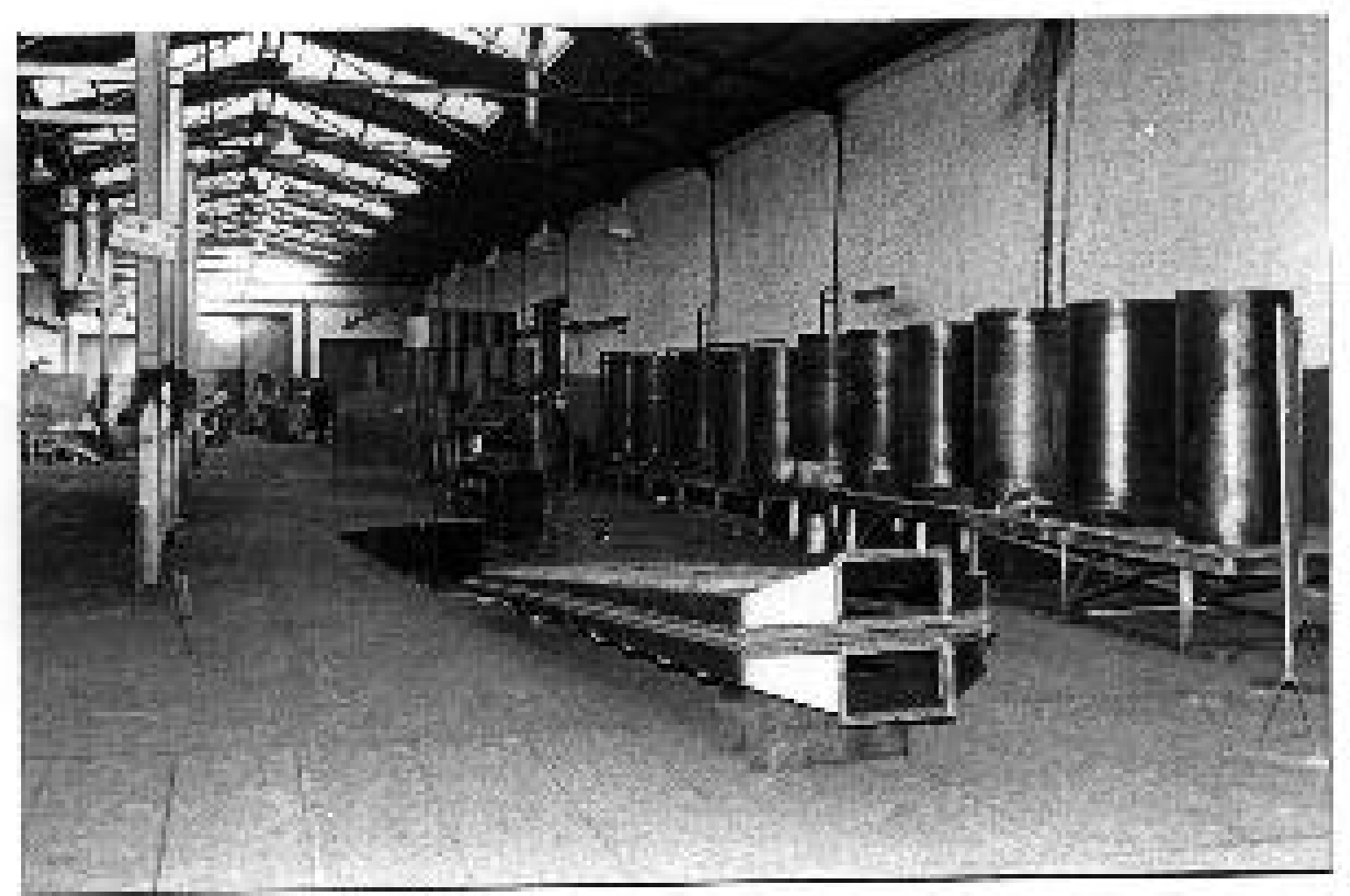

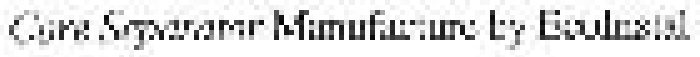


Flame?

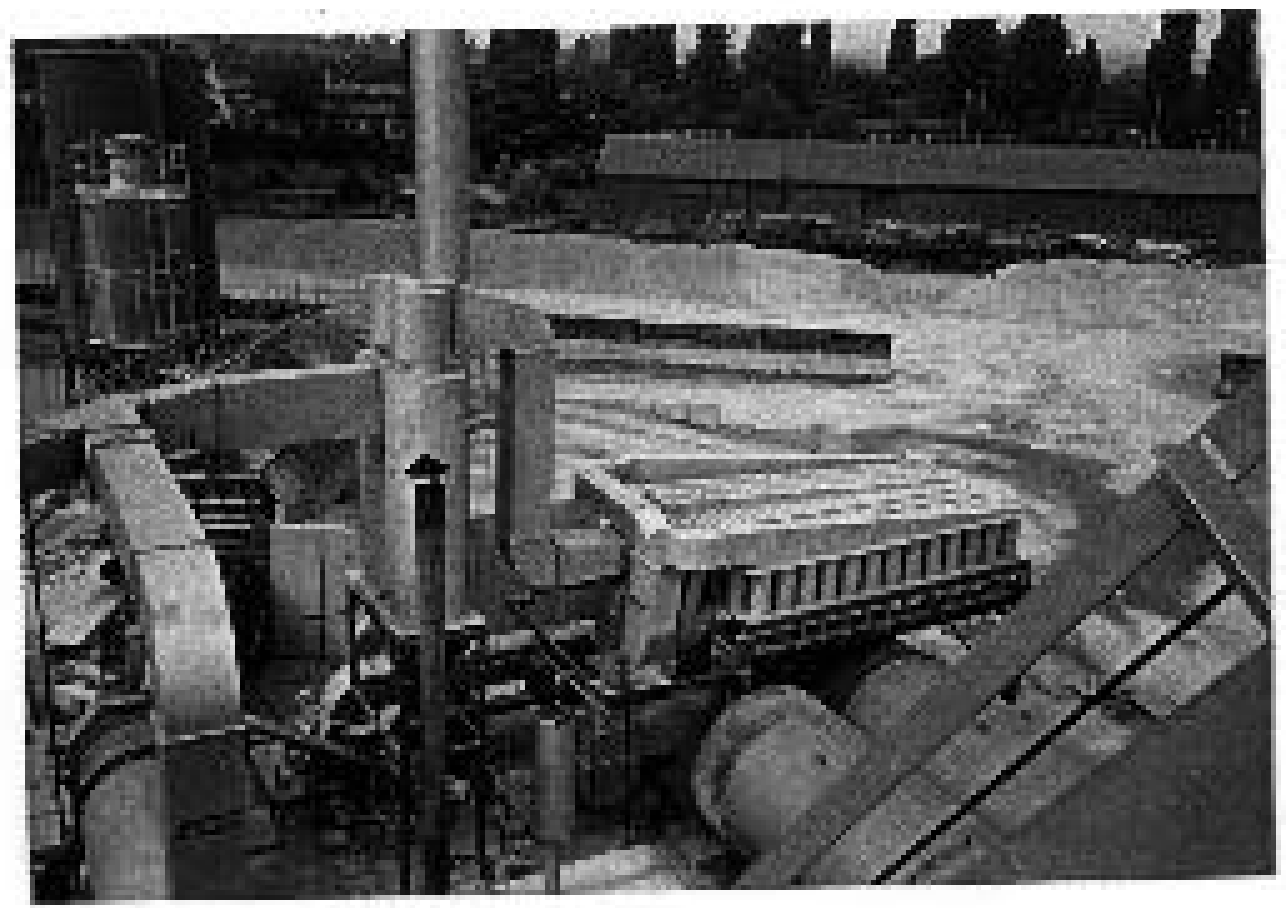

\section{Higirs 4}

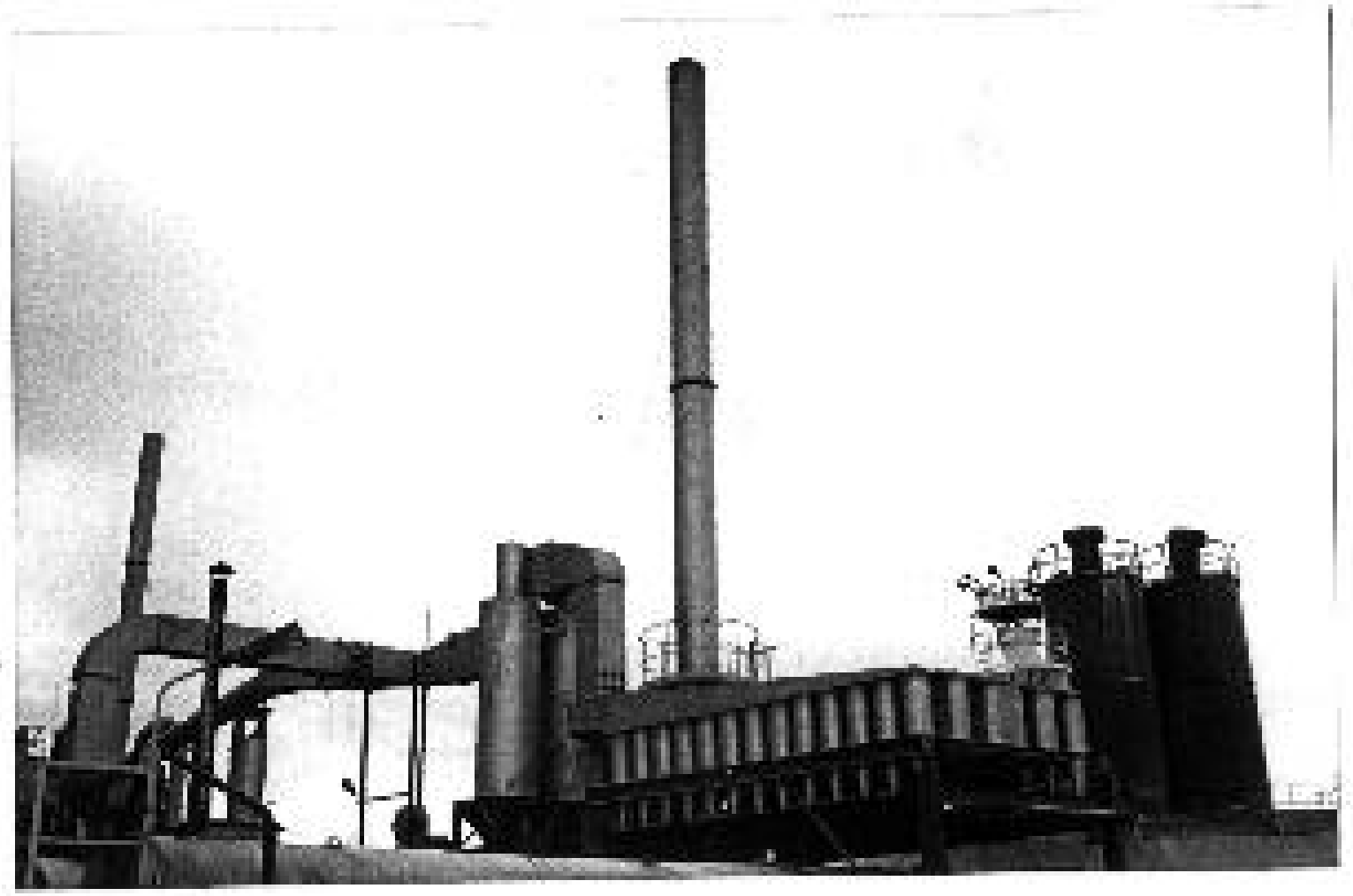

Care Symour Lasnllmin in Kmaw 


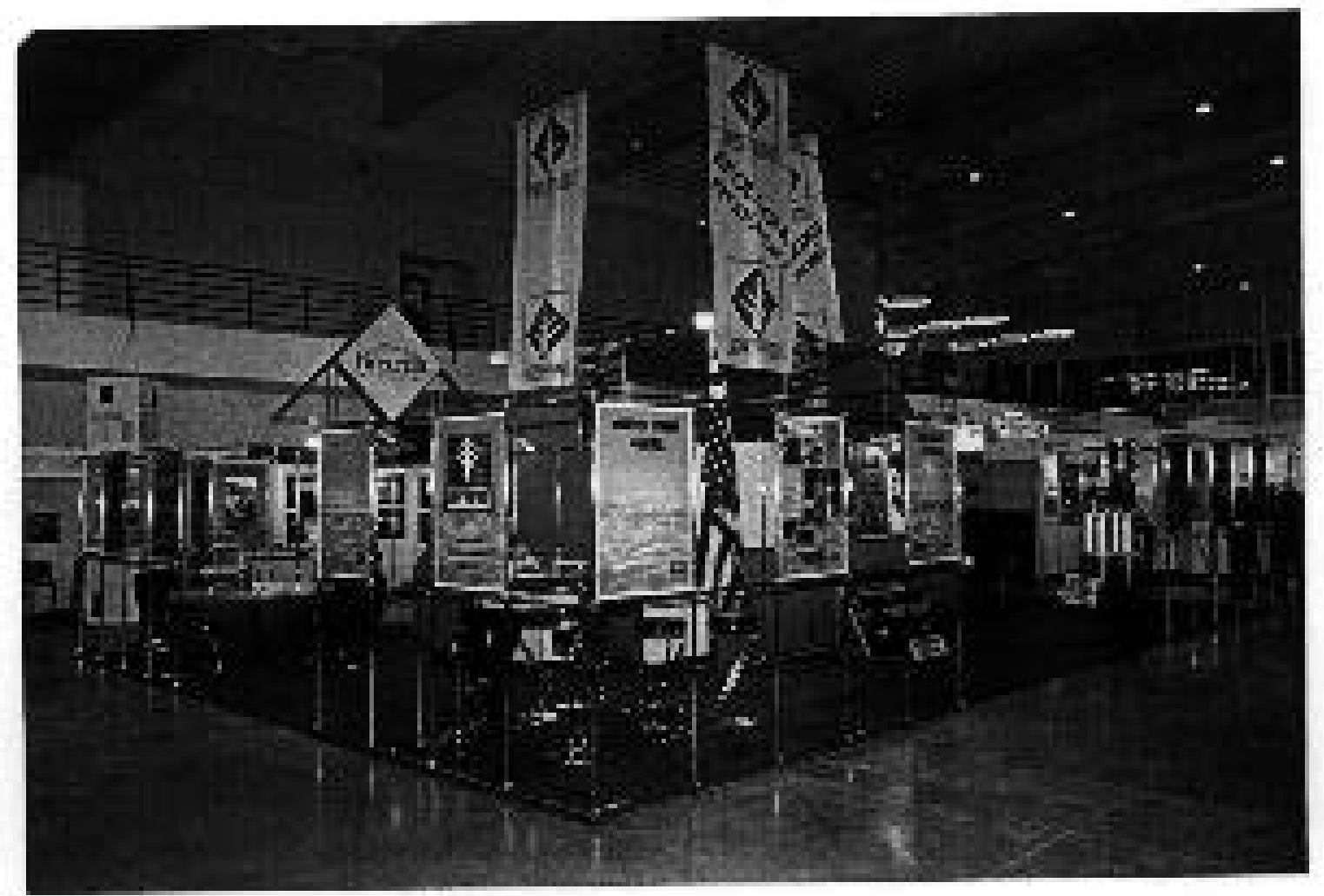

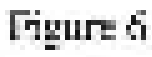

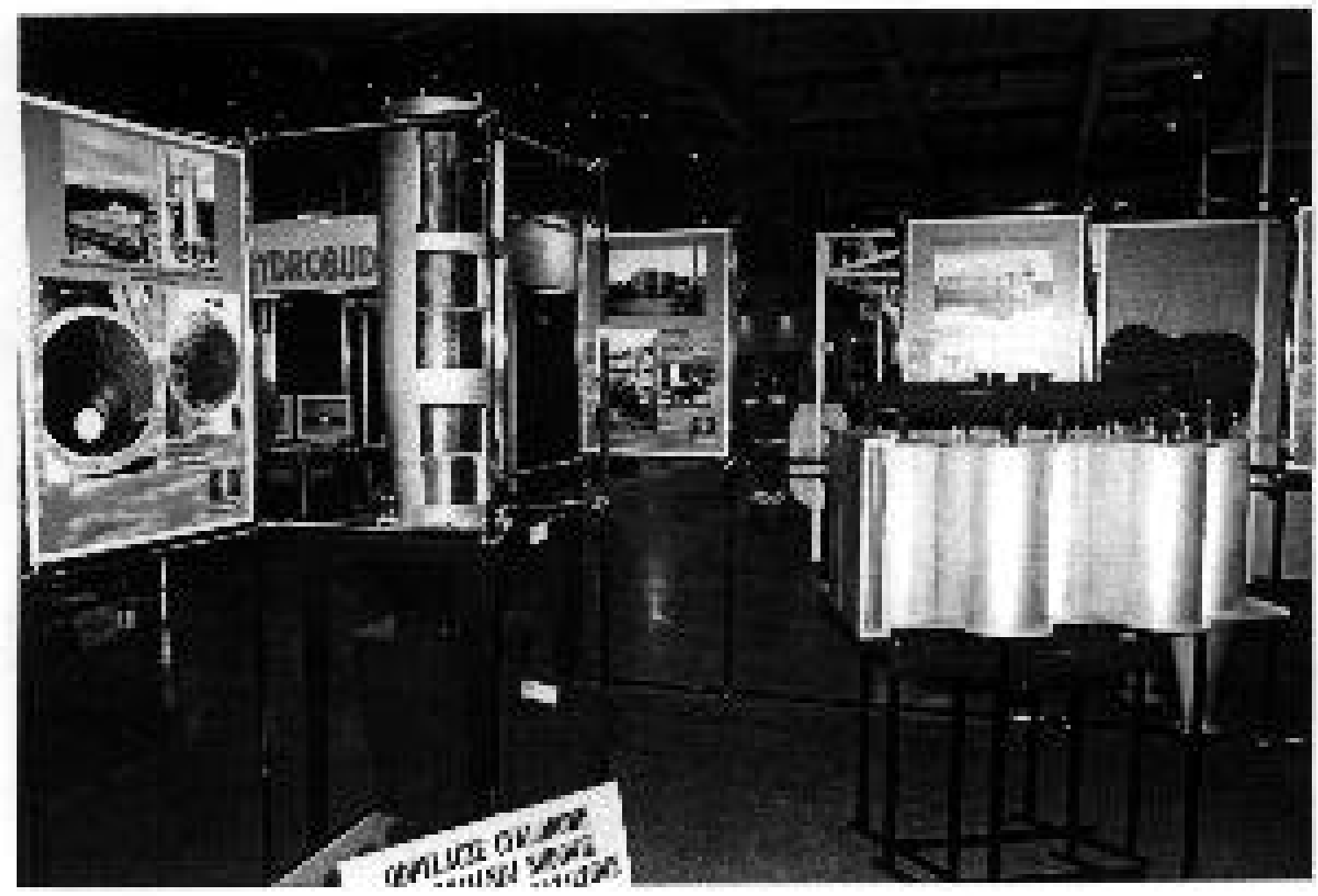

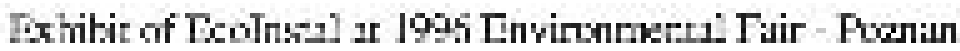


